\title{
Granulomatous disease associated with pulmonary deposition of titanium
}

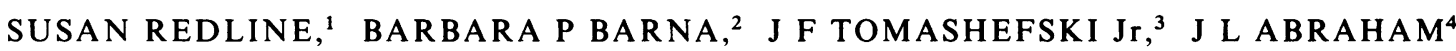

From the Department of Medicine, ${ }^{1}$ Cleveland Metropolitan General Hospital, Case Western Reserve University, and Channing Laboratory, Harvard Medical School and Brigham and Women's Hospital, Boston, Massachusetts, Department of Immunopathology, ${ }^{2}$ Cleveland Clinic Foundation, Cleveland, Ohio, Department of Pathology, ${ }^{3}$ Cleveland Metropolitan General Hospital, Case Western Reserve University, and the Department of Pathology, ${ }^{4}$ Upstate Medical Center, State University of New York, New York, USA

\begin{abstract}
A patient presented with granulomatous lung disease associated with the pulmonary deposition of various metallic particles. To evaluate the relation between the metallic dust and the granulomatous process, lymphocyte transformation tests to aluminium sulphate, titanium chloride, beryllium sulphate, and nickel sulphate were performed. A lymphocyte proliferative response to titanium chloride was observed on two separate occasions; no responses to the other metals were shown. These results are consistent with hypersensitivity to titanium, and suggest, in this individual, a possible aetiological role between the inhalation of titanium and a granulomatous disease process.
\end{abstract}

Granulomatous disease of the lung may occur in response to a variety of infections or as a result of the inhalation of several inorganic substances. ${ }^{12}$ In granulomatous processes where a specific causative agent cannot be identified sarcoidosis may be suggested, based on characteristic but non-specific clinical, radiological, serological, and morphological findings. ${ }^{3}$ A search for aetiological agents in the granulomatous process is often unrewarding. Establishing a causal relation between exogenous particulates that may be identified in tissue specimens and the granulomas, however, may be facilitated by the demonstration of a specific host immune response.

We describe a patient who presented with clinical and light microscopic findings initially suggestive of sarcoidosis. Scanning electron microscopy (SEM) with energy dispersive $x$ ray analysis (EDXA) of a transbronchial biopsy specimen from the patient's lung showed that the pulmonary granulomas contained large numbers of metallic particulates. Cellular immunological studies showed abnormal lymphocyte transformation tests (LTTs) to titanium chloride and normal responses to aluminium, nickel, and beryllium. This is the first time that an abnormal host immune response to titanium has been reported and suggests that titanium, a substance whose patholo- gical effects in occupationally exposed individuals hæ been disputed, may occasionally induce a gran lomatous pulmonary reaction.

\section{Clinical and laboratory findings}

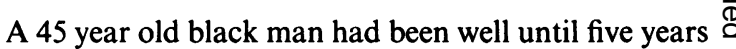
previously (1978) when he noted progressive dys- $\overrightarrow{\overrightarrow{0}}$ pnoea associated with a non-productive cough. Respiratory symptoms, which initially occurred only at work, were subsequently experienced throughout the day. He had no known exposure to individuals with tuberculosis and had no other medical problems. He had worked for the past 13 years as a furnace feeder for an aluminium smelting company where he was exposed to various metallic fumes and dusts released $\delta$ in the production of aluminium and zinc alloys. He worked in an enclosed area outside a firebrick furnace.

Physical examination showed scattered inspiratory crackles in both lung fields. A chest radiograph showed diffuse bilateral fibronodular infiltrates, most prominent in the lower lung zones. Pulmonary func- of tion tests showed a mild restrictive ventilatory $N$ impairment (forced vital capacity $3.41(65 \% \mathrm{P})$; forced expiratory volume in one second $2.01(68 \% \mathrm{P})$; total lung capacity $4.51(69 \% \mathrm{P})$; residual volume 1.41 $(68 \% \mathrm{P}))$. Tuberculin, Candida, and mumps skin tests were non-reactive. Sputum cultures yielded no pathogens. 


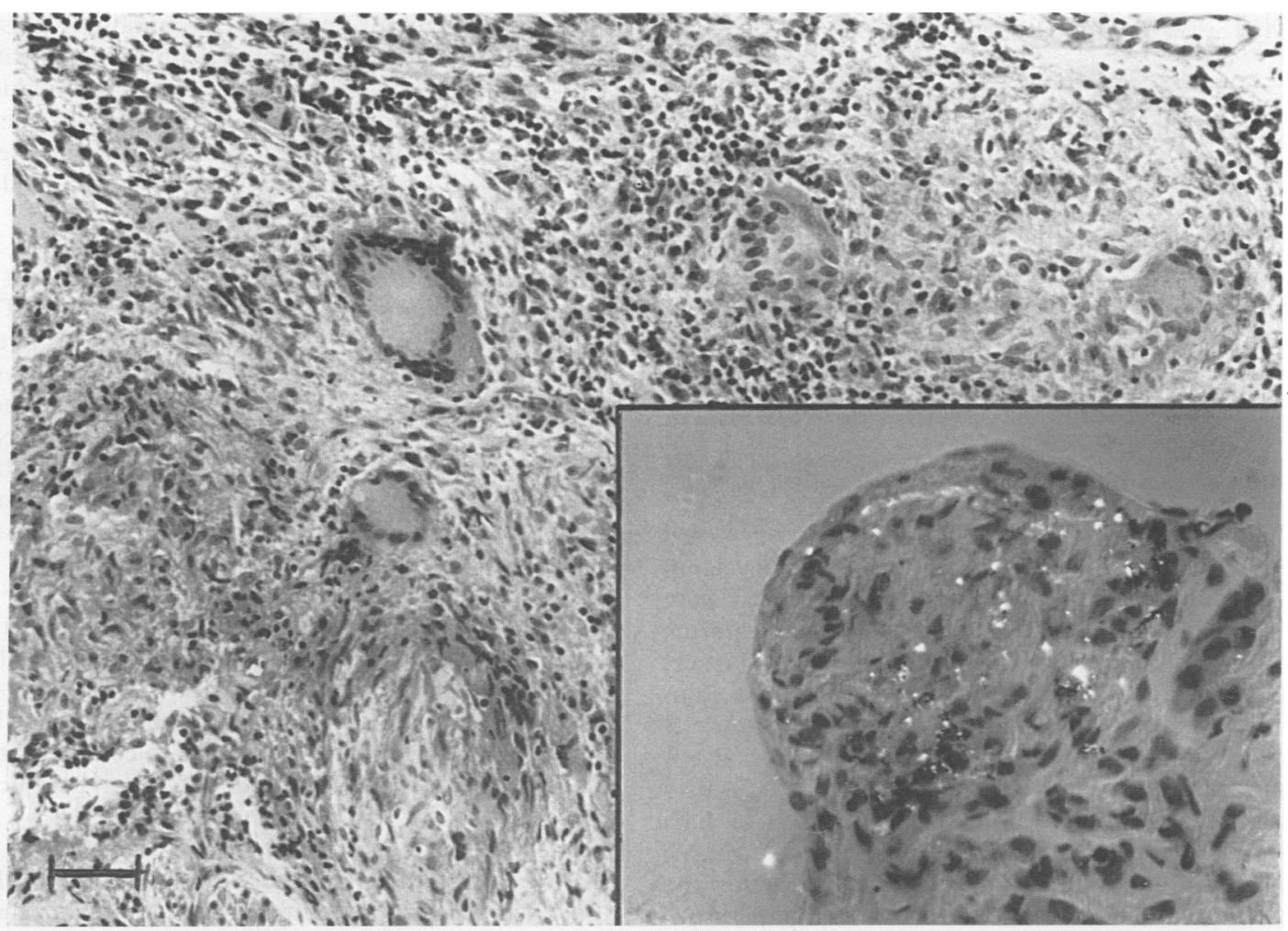

Photomicrograph showing confluent non-caseating granulomas, with numerous giant cells, in wall of bronchiole.

(Haematoxylin and eosin, scale $=50 \mu \mathrm{m})$. Insert. Parenchymal granuloma containing birefringent particles

( Haematoxylin and eosin, partially polarised light, scale $=26 \mu \mathrm{m}$ ).

Other laboratory tests included a normal angiotensin converting enzyme level and negative assays for antinuclear antibody and rheumatoid factor. A gallium scan of the lung was normal. Fiberoptic bronchoscopy showed the airways to be seriously and diffusely erythematous. A differential leukocyte count of bronchoalveolar fluid obtained from segmental pulmonary lavage showed $25 \%$ lymphocytes, $8 \%$ polymorphic leukocytes, and $67 \%$ macrophages.

\section{LIGHT MICROSCOPY}

A transbronchial biopsy from the right lower lobe showed multiple non-caseating granulomas containing numerous birefirengent crystals (fig). Results of microscopic examination of the tissue with special stains for mycobacteria and fungi were negative.

SEM AND EDXA

The lung tissue was further quantitatively analysed for particulates with SEM and EDXA techniques previously described ${ }^{4}$ and found to contain $1.39 \times 10^{9}$ exogenous particulates $/ \mathrm{cm}^{3}$ tissue. The particulates consisted of various metallic alloys containing aluminium in combination with other metals, including titanium, zinc, and nickel (61\%), various aluminium silicates $(35 \%)$, and silica (2\%) (table 1$)$.

\section{CELLULAR IMMUNOLOGICAL STUDIES}

Lymphocyte transformation tests were performed as previously described. ${ }^{5}$ Briefly, mononuclear leukocytes were isolated by centrifugation of heparinised peripheral blood over Ficoll-Hypaque (Pharmacia, Piscataway, NJ) and resuspended in RPMI 1640 supplemented with $10 \%$ human AB serum, $100 \mathrm{mM} \mathrm{l-}$ glutamine, and antibiotics (GIBCO, Grand Island, NY). Leukocyte suspensions were added to microtitre plates at $2 \times 10^{5}$ cells $/$ wells in $0.2 \mathrm{ml}$ medium. Four replicate wells were used for each variable tested. Mitogens used were Phytohemagglutinin (PHA) (Difco, Detroit, MI), $200 \mu \mathrm{g} / \mathrm{ml}$; Pokeweed Mitogen (PWM) (GIBCO), $20 \mu \mathrm{l} /$ well of a 1:5 dilution of manufacturer's stock; and Concanavalin A (CON A) 
Table 1 Major elements found in metal particles by SEM and $E D X A^{*}+$

\begin{tabular}{llr}
\hline Element & No per $\mathrm{ml}$ per tissue $\neq$ & $c p s / \mathrm{ml}$ Tissue \\
\hline Aluminium & $4.9 \times 10^{8}$ & $78.3 \times 10^{9}$ \\
Iron & $3.0 \times 10^{8}$ & $42.2 \times 10^{9}$ \\
Titanium & $1.7 \times 10^{8}$ & $22.8 \times 10^{9}$ \\
Zinc & $1.1 \times 10^{8}$ & $2.7 \times 10^{9}$ \\
Lead & $0.3 \times 10^{8}$ & $2.5 \times 10^{9}$ \\
\hline
\end{tabular}

*Other metals noted at lower concentrations: $\mathrm{Cu}, \mathrm{Ni}, \mathrm{Mn}, \mathrm{Cr}, \mathrm{Ag}$, $\mathrm{Mo}, \mathrm{Mg}$.

†Metals associated within single particles (possible alloys):

$\mathrm{Al}$ with: $\mathrm{Ti}$ and $\mathrm{Fe} ; \mathrm{Zn} ; \mathrm{Ni}, \mathrm{Cu}$, and $\mathrm{Fe} ; \mathrm{Ti} ; \mathrm{Mn} ; \mathrm{Zn}$ and $\mathrm{Ti} ; \mathrm{Zn}$ and $\mathrm{Mg}$; $\mathrm{Ti}$ and $\mathrm{Mg}$. Fe with: $\mathrm{Ti} ; \mathrm{Mn} ; \mathrm{Cr}$ and $\mathrm{Mo}$. $\mathrm{Pb}$ with: $\mathrm{Cr}$.

$\ddagger$ Numbers of metal particles containing a given element per $\mathrm{ml}$ tissue. $\S$ Total $x$ ray counts per second.

\|Tissue concentration estimated to be $10 \mathrm{ppm}$ (based on data correlating bulk analytic technique with in situ microanalytic method. ${ }^{4}$

(Miles, Elkhart, IND), $20 \mu \mathrm{g} / \mathrm{ml}$. Metal salts used were beryllium sulphate (Brush-Wellman, Cleveland, $\mathrm{OH}$ ), titanium chloride (Fisher Scientific, Fairlawn, NJ), nickel sulphate (Fisher), and aluminium chloride (Baker, Phillipsburg, NJ). Titanium oxide (Fisher) was used in a single assay but because of poor solubility was not included in further tests. The metal salts were added to cultures so as to yield final concentrations ranging from 0.01 to $100 \mu \mathrm{g} / \mathrm{ml}$. Cultures were incubated for 96 hours with inclusion of $1 \mathrm{Ci}$ tritiated thymidine (specific activity, $5 \mathrm{Ci} / \mathrm{mM}$, Amersham International, Amersham, UK) for the last 20 hours. Cells were collected on filter paper discs with an automatic harvester and the discs were analysed for radioactive content in a liquid scintillation counter; data were expressed as counts per minute (cpm). The results were defined as positive if the mean $\mathrm{cpm}$ from metal salt containing wells divided by the mean cpm from control wells (wells containing cells in medium alone) yielded a quotient equal to or greater than $2 \cdot 0$, a number also referred to as a stimulation index (SI), and if the difference between the mean cpms of the control and the metal salt containing wells was statistically significant with the $t$ test $(\mathrm{p}<0.05)$.

\section{RESULTS OF IMMUNOLOGICAL TESTING}

Lymphocyte transformation tests were carried out at four different times over a period of a year. The patient's lymphocyte responses to mitogens were severely depressed while he was being treated with $60 \mathrm{mg}$ prednisone daily (table $2 \mathrm{~A}$ ). Thereafter, responses improved but fluctuated below the mean values of established normals. The patient's lymphocytes were challenged with titanium chloride, aluminium chloride, nickel sulphate, and beryllium sulphate. On two occasions, corresponding to times of maximum mitogen responsiveness, significantly $(\mathrm{SI} \geqslant$ $2.0, p<0.05$ ) raised lymphocyte responses occurred in the presence of $10 \mu \mathrm{g} / \mathrm{ml}$ titanium chloride (table 2B). Negative lymphocyte responses were seen when challenged with 0.01 to $0.10 \mu \mathrm{g} / \mathrm{ml}$ aluminium chloride (times $1-4), 0 \cdot 2$ to $100 \mu \mathrm{g} / \mathrm{ml}$ nickel sulphate (times 1 and 2), or to 0.2 to $10 \mu \mathrm{g} / \mathrm{ml}$ beryllium sulphate (time 3 )* (all SIs no greater than 1.4).

Lymphocytes from three painters (mean age $46 \cdot 2 \pm$ 16.1 (SD) years; mean duration of paint exposure 21.8 \pm 6.5 years) who used titanium based paints in thei work and three unexposed individuals (medical peko sonnel) also were challenged with metal salts. Nonẹ

*Beryllium was tested because of its known relation with granulomatous disease. Beryllium cannot be identified with SEM and EDXA.

Table 2 Lymphocyte transformation responses to mitogens and to titanium chloride

\begin{tabular}{|c|c|c|c|c|c|c|c|c|c|c|}
\hline \multirow[t]{3}{*}{ (a) } & & \multicolumn{9}{|c|}{ Mitogen responses. Mean counts per minute (cpm) of lymphocyte cultures } \\
\hline & & \multirow{2}{*}{\multicolumn{3}{|c|}{ Normal responses* }} & \multicolumn{6}{|c|}{ Patient's responses } \\
\hline & & & & & 13.9.83 & & 8.6.84 & & 25.6 .84 & 17.8.84 \\
\hline \multicolumn{2}{|c|}{$\begin{array}{l}\text { Phytohaemagluttin (PHA) } \\
\text { Pokeweed mitogens (PWM) } \\
\text { Concavalin A (Con A) } \\
\text { Daily prednisone dose (mg) }\end{array}$} & $\begin{array}{l}88086 \\
34396 \\
69300\end{array}$ & & & $\begin{array}{r}52110 \\
16265 \\
23664 \\
60\end{array}$ & & $\begin{array}{r}104345 \\
23901 \\
50241 \\
10\end{array}$ & & $\begin{array}{r}82656 \\
16454 \\
30691 \\
10\end{array}$ & $\begin{array}{r}92461 \\
22768 \\
41251 \\
10\end{array}$ \\
\hline \multirow[t]{2}{*}{ (b) } & \multicolumn{10}{|c|}{ Lymphocyte responses to titanium chloride } \\
\hline & $\begin{array}{l}\overline{13.9 .8} \\
\text { Mean }\end{array}$ & $m+S D$ & $S I \dagger$ & $\begin{array}{l}8.6 .84 \\
\text { Mean cpm + SD }\end{array}$ & SI† & $\begin{array}{l}25.6 .84 \\
\text { Mean cpm }\end{array}$ & $+S D$ & $S I+$ & $\begin{array}{l}17.8 .84 \\
\text { Mean cpm + SD }\end{array}$ & $S I+$ \\
\hline $\begin{array}{l}\text { Thymidine } \\
\text { incorporation to } \\
\text { titanium chloride }\end{array}$ & $360 \pm$ & & $1 \cdot 3$ & $900 \pm 62$ & $2 \cdot 1 \ddagger$ & $275 \pm 50$ & & $1 \cdot 1$ & $450 \pm 100$ & $2 \cdot 0 \pm \S$ \\
\hline $\begin{array}{l}\text { Thymidine } \\
\text { incorporation in } \\
\text { medium alone }\end{array}$ & $277=$ & & & $428 \pm 137$ & & $250 \pm 50$ & & & $220 \pm 50$ & \\
\hline
\end{tabular}

*Control values obtained by testing 50 normal subjects.

$+\mathrm{SI}=$ Stimulation index; calculated by dividing the mean $\mathrm{cpm}$ in the presence of titanium chloride by the mean cpm in medium alone. $\ddagger p<0.05$ by Student's $t$ test comparing mean cpm in presence of titanium chloride with mean cpm in medium alone.

$\S A$ SI of 2.0 was also shown in culture with $1.0 \mu \mathrm{g} / \mathrm{ml}$ titanium chloride. 
of these controls showed significant lymphocyte responses to titanium chloride, aluminium chloride, beryllium sulphate, or nickel sulphate, as shown by SIs less than 1.4 (data not shown).

\section{Discussion}

Granulomatous lesions may result from persistent antigenic stimulation of the immune system. ${ }^{6}$ In sarcoidosis an unidentified antigen is thought to activate $\mathrm{T}$-lymphocytes to release lymphokines that stimulate a cellular immune response leading to alveolitis and granuloma formation. ${ }^{7-10}$ In chronic berylliosis a specific metal has been shown as the relevant antigen in a morphologically similar disease process. $^{11}$

In the present case of granulomatous pulmonary disease alloy like particles of aluminium with titanium and other metals were identified within lung tissue at a concentration 100-fold above the "background" lung burden. ${ }^{4}$ (The concentration of silica particles was lower than seen in cases of silicosis. ${ }^{4}$ ) To investigate the relation between the metallic particulates and the granulomatous disease, we measured delayed type hypersensitivity responses to identified metals with LTTs. The demonstration of significantly raised proliferative responses of the patient's lymphocytes to titanium chloride tested at times at maximum mitogen responsiveness, and a high concentration of titanium within the pulmonary granuloma, may suggest an aetiological association between the titanium dust and the granulomatous process. The metallic salts used in these assays had no non-specific mitogenic properties, as shown by the lack of lymphocyte responses in non-exposed controls. The type of beryllium used in this study has been previously found not to be mitogenic nor to induce lymphocyte transformation in unsensitised individuals. ${ }^{12}$

The biological effects of the inhalation of various titanium compounds are uncertain. The demonstration of substantial quantities of titanium in human necropsy lung specimens unassociated with significant tissue reaction has led to the suggestion that titanium is biologically inert. ${ }^{1314}$ Titanium dust inhalation in animals, however, has been associated with the finding of increased numbers of pulmonary phagocytic cells, small pulmonary granulomas, and areas of lung fibrosis. ${ }^{1516}$ Human morphological studies have shown that titanium dust is phagocytised by pulmonary alveolar macrophages, aggregates within lysosomes, and may enter the lymphatic circulation. ${ }^{17}$ It may be postulated that titanium, although too small to act as an antigen alone, may react with tissue macromolecules to acquire immunogenicity.

A few clinical studies suggest that workers with long term occupational exposure to titanium produc- tion processes may develop pulmonary fibrosis. ${ }^{1819}$ A causal relation between the titanium and the observed pulmonary changes, however, could not be proved in these studies because of confounding exposures with other toxic substances. Granulomatous pulmonary disease has been described previously in a titanium worker, but in that report exposure to beryllium was not excluded, and specific immunological testing for titanium hypersensitivity was not performed. ${ }^{20}$

In the case presented here sensitisation to titanium is suggested by the lymphocyte proliferative response to this metal (SIs $\geqslant 2 \cdot 0$ ) shown at times at maximum mitogen responsiveness, a criterion used successfully to differentiate patients with chronic berylliosis from controls. ${ }^{11}$ Rarely, however, SIs $>2 \cdot 0$ to beryllium have been found in healthy beryllium workers. ${ }^{21} \mathrm{We}$ therefore tested the hypothesis that the titanium induced lymphocyte responses observed were not related to the granulomatous process in the lungs, but represented a coincidental, non-pathological immunological reaction to titanium that regularly occurs after exposure to titanium. We studied lymphocyte transformation responses to titanium in three healthy controls exposed to titanium. Chronic exposure to titanium in these individuals did not lead to sensitisation.

The magnitude of the lymphocyte responses to titanium, although lower than that observed in many cases of berylliosis, was consistent with lymphocyte responses measured in subjects with well established chronic berylliosis treated with corticosteroids. ${ }^{12}$ Similarly to what has been observed in subjects with berylliosis, specific lymphocyte activity varied with mitogen responsiveness (B Barna, unpublished data). Thus higher lymphocyte responses to titanium chloride might have been observed if the patient had been tested in the absence of steroid treatment. Testing of lymphocytes obtained with bronchoalveolar lavage may also have increased the likelihood of detecting immunological sensitisation. ${ }^{22}$

The relatively few cases of pulmonary disease reported in association with exposure to titanium dust is consistent with the notion that sensitisation to titanium may be based on idiosyncratic host response mechanisms. Recent animal studies suggest that differences in susceptibility to metallic dusts may be related to genetic differences in immunoreactivity. ${ }^{2324}$ The relation between immunoreactivity and disease susceptibility requires further investigation.

In conclusion, in a patient with fibronodular pulmonary infiltrates and multiple occupational exposures $x$ ray microanalytical techniques were used specifically to identify the composition of crystalline particulates detected by light microscopy within pul- 
monary granulomas. Immunological testing subsequently showed a possible sensitisation to titanium, a substance whose role in pathological processes has been disputed. These findings suggest the possibility that a specific inorganic dust may have been aetiological in a granulomatous process that was initially classified as sarcoidosis. More precise immunological studies of systemic reactions to exogenous particles may further clarify the role of occupational exposures in pathological processes.

We thank Dr Murray Altose and Dr David Gillespie for their encouragement, Dr Frank E Speizer for his critical review of the manuscript, and Dr Mohammed Lankerani for his help in the review of the pathological material. We also thank Ms Donna McCobb and Ms Jean Fuller for their expert secretarial help. Supported in part by Institutional National Research Service Award (HLO7427) from the National Institutes of Health.

\section{References}

1 Warren KS. A functional classification of granulomatous inflammation. Ann NY Acad Sci 1976;278:7-18.

2 Boros DL. Granulamatous inflammations. Prog Allergy 1978;24:183-267.

3 Mitchell DN, Scadding JG. Sarcoidosis. Am Rev Respir Dis 1974;110:774-802.

4 Abraham JL, Burnett BR. Quantitative analysis of inorganic particulate burden in in situ tissue sections. Scanning Electron Microscopy 1983;11:681-96.

5 Oppenheim JJ, Schacter B. Lymphocyte transformation. In: Manual of clinical immunology. 2nd ed. Washington: American Society for Microbiology, 1980:233-45.

6 Danielle RP, Dauber JH, Rossman MD. Immunologic abnormalities in sarcoidosis. Ann Intern Med 1980;92:406-16.

7 Crystal RG, Roberts WC, Hunninghake GW, Gadek JE, Fulmer JD, Line BR. Pulmonary sarcoidosis: a disease characterized and perpetuated by activated lung t-lymphocytes. Ann Intern Med 1981;94:73-94.

8 Hunninghake GW, Bedell GN, Zavala DC, Monick M, Brady M. Role of interleukin-2 release by lung $\mathrm{T}$-cells in active pulmonary sarcoidosis. Am Rev Respir Dis 1983;128:634-8.
9 Hunninghake GW. Release of interleukin-1 by alveolar macrophages in patients with active pulmonary sarcoidosis. Am Rev Respir Dis 1984;129:569-72.

10 Cueppens JL, Lacquet LM, Mariën G, Demedts $M$, van den Eeckhout A, Stevens E. Alveolar t-cell subsets in pulmonary sarcoidosis. Am Rev Respir Dis 1984;129:563-8.

11 Williams WR, Williams WJ. Development of beryllium lymphocyte transformation tests in chronic beryllium disease. Int Arch Allergy Appl Immunol 1982;67:175-80.

12 Deodhar SD, Barna B, Van Ordstrand HS. A study of the immunologic aspects of chronic berylliosis. Chest 1973;63:309-13.

13 Schnitz-Moorman P, Horlein H, Hanefeld F. Lung enveranderosis bei titandioxydstaubeeposition. Silikosefjarsh 1984;80:1-17.

14 Rode LE, Ophus EM, Gylseth B. Massive pulmonary deposition of rutile after titanium dioxide exposure: light-microscopical and physico-analytical methods in pigment identification. Acta Pathol Microbiol Scand 1981;89:455-61.

15 Dale K. Early effects of quartz and titanium dioxide dust on pulmonary function and tissue. Scand $J$ Respir Dis 1973;54:168-84.

16 Gross P, Kociba RJ, Sparschu GL, Norris JM. The biologic response to titanium phosphate. Arch Pathol Lab Med 1977;101:550-4.

17 Maatta K, Arstila A. Pulmonary deposits of titanium dioxide in cytologic and lung biopsy specimens. Lab Invest 1975;33:342-6.

18 Elo R, Maatta K, Uksila E, Arstila AV. Pulmonary deposits of titanium dioxide in man. Arch Pathol 1972;94:417-24.

19 Daum S, Anderson HA, Lilis R, et al. Pulmonary changes among titanium workers. Proceedings of the Royal Society of Medicine 1977;70:31-2.

20 Angebault M, Berland M, Parent G, Bonniot JP, Hamasson JP. Toxicite pulmonaire du bioxyde de titane, risque lie au poncage des mastics. Archives des Maladies Professionelles de Médicine du Travail et de Securité Sociale 1979;40:501-8.

21 Williams WJ, Williams WR. Value of beryllium lymphocyte transformation tests in chronic beryllium disease and in poten= tially exposed workers. Thorax 1983;38:41-4.

22 Barna BP, Deodhar SD, Chiang T, Gautam S, Edinger M. Experif mental beryllium-induced lung disease: differences in immunologic responses to beryllium compounds in strains 2 and 13 guinea pigs. Int Archs Allergy Appl Immunol 1984;73:42-8.

23 Barna BP, Deodhar SD, Gautman S, Edinger M, Chiang T, McMahon JT. Experimental beryllium-induced disease: analysis of bronchial lavage cells in strains 2 and 13 guinea pigs. Int Archs Allergy Appl Immunol 1984;73:49-55.

24 Danielle RP, Elias JA, Epstein PE, Rossman MD. Bronchoalveolar lavage: role in pathogenesis, diagnosis, and management of interstitial lung disease. Ann Intern Med 1985;102:93-108 